\title{
Growth and Carbon Storage Potential of Important Agroforestry Trees of North-West Himalaya
}

\author{
S.R. Roshanzada, K.S. Pant* and S. Kar \\ Department of Silviculture and Agroforestry, College of Forestry, Dr. YS Parmar University \\ of Horticulture and Forestry, Nauni, Solan 173220, India \\ *Corresponding author
}

\begin{tabular}{|l|}
\hline K e y w o r d s \\
$\begin{array}{l}\text { Growth, Carbon storage, } \\
\text { Allometric equation, Total } \\
\text { biomass, Albizia chinensis, } \\
\text { Albizia lebbeck, Acacia } \\
\text { mollissima, Dalbergia sissoo, } \\
\text { Toona ciliata, Melia } \\
\text { composita and Ulmus villosa }\end{array}$ \\
\hline Article Info \\
\hline $\begin{array}{l}\text { Accepted: } \\
15 \text { October } 2018 \\
\text { Available Online: } \\
10 \text { November } 2018\end{array}$ \\
\hline
\end{tabular}

\section{Introduction}

Forestry play an important role in regional and global carbon (C) cycle because they store large quantities of $\mathrm{C}$ in vegetation and soil, exchange $\mathrm{C}$ with the atmosphere through photosynthesis and respiration and are source of atmospheric $\mathrm{C}$ when they are disturbed by human or natural causes, become atmospheric $\mathrm{C}$ sink during re-growth after disturbance, and
Growth, biomass, carbon storage and allometric relations for estimating stem volume and aboveground biomass on the basis of $\mathrm{DBH}$ and Height of tree and growth pattern curve, carbon storage and developed various allometric equations on selected Agroforestry trees. Total seven species including 210 trees were marked selected in the present study. The maximum adjust $\mathrm{R}^{2}$ found in; Albizia chinensis where quadratic function showed the highest adj $\mathrm{R}^{2}(0.993)$ on the basis of DBH and according to the height of tree $(\mathrm{H})$, the best fit was also quadratic, which showed adj $R^{2}$ in the value of $(0.695)$, on the other hand for six species trees, power function was the best significant equation which modified the highest adj $\mathrm{R}^{2}$ for the following specieses, that are Albizia lebbeck (0.964), Acacia mollissima (0.992), Melia composita (0.990), Dalbergia sissoo (0.992), Toona ciliata (0.888) and Ulmus villosa (0.990) recorded on the basis of $\mathrm{DBH}$, however, to the height of tree as an independent variable, the best equation was sigmoid which showed the adj $\mathrm{R}^{2}$ value in Albizia lebbeck (0.480), Acacia mollissima (0.530), Melia composita (0.598), Dalbergia sissoo (0.551), Toona ciliata (0.645) and Ulmus villosa (0.597). The total biomass (AGB + BGB) was calculated using specific gravity and root-shoot ratio. Branch and leaves biomass of each species was estimated using biomass expansion factor (BEF) of trees as per the guidelines of IPCC (2003). All biomass values were converted to tree biomass carbon by multiplying factor of 0.5 . However, in this research, equation selection was based on adjust $\mathrm{R}^{2}$ and minimum standard error. 
as they account for 60 percent of terrestrial carbon storage (Wilson and Daff, 2003). Forest ecosystem is one of the most important carbon sinks of the terrestrial ecosystem. It uptakes the carbon dioxide by the process of photosynthesis and stores the carbon in the plant tissues, forest litter and soils. As more photosynthesis occurs, more $\mathrm{CO}_{2}$ is converted into biomass, reducing carbon in the atmosphere and sequestering it in plant tissue above and below ground (Gorte, 2009; IPCC, 2003) resulting in growth of different parts (Chavan and Rasal, 2010).

Allometry, generally relates some non-easy to measure tree characteristics from easily collected data such as dbh (diameter at breast height), total height or tree age and provides relatively accurate estimates. Models for volume, biomass or nutrient content within the trees belong to the same class as methodologies for sampling trees and fitting and using the equations are similar. Despite their apparent simplicity, these models have to be built carefully, using the latest regression techniques.

Tree growth parameters varies considerably with species, site quality, location, climatic regimes, altitude etc. and therefore becomes necessary to obtain accurate and precise tree allometric estimates in order to improve understanding of the role of these carbon sinks in global carbon cycle. An unsuitable application of allometric equation may lead to considerable bias in carbon stocks estimations (Henry et al., 2013).

\section{Materials and Methods}

\section{Site description}

The study was conducted in out in, Dr Y S Parmar University of Horticulture and Forestry, Nauni area, Solan Himachal Pradesh, India. The area lies about 13 kilometres from
Solan between 30 o 5030 to 30 o $520 \mathrm{~N}$ latitude and the longitude 77o8 30 and 77o11 30 E (Survey of India Toposheet No. 53F/1) with an elevation of about 900-1300 m above mean sea level. The minimum and maximum temperature varies from $3^{\circ} \mathrm{C}$ during winter (January) to $33^{\circ} \mathrm{C}$ during summer (June), whereas; mean annual temperature (MAT) is $19^{\circ} \mathrm{C}$.

\section{Biomass sampling}

Seven species (each species 30 trees) were measured for their diameter at breast height (DBH) and height with tree calliper and Ravi's altimeter, respectively. Biomass of the stem is determined by multiplying volume of stem with specific gravity. Local volume equation developed for specific tree species and region was used for calculating the volume of the forest trees, Branch and leaves biomass was estimated by multiplying the volume of trees of each species with their corresponding biomass expansion factors,

The total aboveground biomass of the tree comprised of the sum of stem biomass, branch biomass and leaf biomass, The below ground biomass (BGB) calculated by multiplying above ground biomass taking 0.26 as the root: shoot ratio and for total biomass were calculated sum of above ground biomass and belowground biomass.

\section{Growth}

To find the growth were calculated growth parameter (crown area, crown width, crown volume and height of the tree)

\section{Crown area}

Crown area will be assumed to be a circle, and it was calculated and used the formula given by Chaturvedi and Khanna (2000) and expressed in meter square. $\mathrm{CA}=\pi \div 4 \mathrm{D}^{2}$. 


\section{Crown width}

The crown width $(\mathrm{m})$ was measured in two directions (North-south and East-west) and average was calculated as:

$\mathrm{CW}=\frac{\mathrm{D} 1+\mathrm{D} 2}{--------}$

\section{Crown volume}

For calculated, used the following formula (Balehegn et al., 2012):

$\mathrm{CV}=4 \pi \div 3+(\mathrm{CW} \div 2+\mathrm{CD} \div 2)^{3}$.

\section{Height of trees}

It is the height from base to top of standing tree measured and used Ravi Millimeter and expressed in meters.

\section{Carbon storage}

Biomass of each tree component converted to biomass-carbon by multiplying biomass with conversion factor of 0.50 .

\section{Statistical procedure}

All the species compared for their morphological characters by using standard statistical procedure.

The allometric relationships among different tree components of an individual tree like height, dbh, biomass and volume developed by using linear and non-linear functions.

\section{Data processing and analysis}

The best linear and nonlinear relationship between tree components determined by determination of (Adj. $\left.\mathrm{R}^{2}\right)$ and standard residual error.

\section{Adjusted $\mathbf{R}^{2}$}

Calculated as per following formula given by Gujrati, 1998.

$\mathrm{R}^{2}=1-\left[^{\frac{\left(1-R^{2}\right)(\mathrm{n}-1)}{n-k-1}}\right]$ Where: $\mathrm{R}=$ sample $\mathrm{R}-$ square, $\mathrm{N}=$ number of observations and $\mathrm{K}=$ number of parameter.

Standard residual error: (Mbow et al., 2013) $\sigma$

$\mathrm{SRE}^{=\frac{\sqrt{\mathrm{n}}}{\mathrm{y}}}$

Where: $\mathrm{y}=$ the average of the observed parameter, $\boldsymbol{\sigma}=$ the standard deviation and $n=$ is the number of sample.

\section{Results and Discussion}

Determination of allometric equation among the tree components

The result on various linear and non-linear functions for tree volume as the dependent variable and DBH (diameter at breast height) and tree Height separately as independent variable for Albizia chinensis, Albizia lebbeck, Melia composita, Acacia mollissima, Toona ciliata, Dalbergia sissoo and Ulmus wallichiana and are present in Table 1.

\section{Albizia chinensis}

The allometric relations for estimating stem volume with DBH and Height of tree , each taken independently , where quadratic Function showed highest $\overline{\mathrm{R}} \quad 2 \quad$ (0.98) stem volume with DBH. In case of tree Height sigmoid function showed highest adj $\overline{\mathrm{R}}^{2}$ (0.69).

The allometric relationship of tree stem biomass with DBH and tree Height , each 
taken independently, where quadratic function showed $\overline{\mathrm{R}}^{2}(0.99)$ for tree stem biomass with DBH. In case of Height of tree sigmoid function showed the highest adj $\overline{\mathrm{R}}^{2}(0.69)$.

Albizia chinensis showed significant allometric relationship for estimating of branch and leaves biomass (BB) with DBH as well as tree Height when used independently. The results revealed that quadratic function was strong with adj $\overline{\mathrm{R}}^{2}$ (0.98). Similarly, stronger relationships were found for tree Height variable with maximum $\overline{\mathrm{R}}^{2}$ values by sigmoid function (0.69).

The allometric relationships of tree above ground biomass (AGB) with DBH and Height of tree , each taken independently, where quadratic Function showed $\overline{\mathrm{R}}^{2}(0.99)$ and In case of tree Height sigmoid function showed $\overline{\mathrm{R}}^{2}(0.69)$.

\section{Albizia lebbeck}

Albizia lebbeck were significant for DBH. The power function showed highest $\overline{\mathrm{R}}^{2}(0.96)$ for volume with DBH and in case of Height of tree power function showed highest $\bar{R}^{2}(0.47)$.

The allometric relations for estimating stem biomass with DBH and Height of tree , each taken independently, where power Function showed highest $\overline{\mathrm{R}}^{2}$ (0.96) stem biomass with DBH and In case of tree Height power function showed highest adj $\overline{\mathrm{R}}^{2}(0.47)$.

Various allometric relationships used for DBH as well as tree Height for branch and leaves estimating of Albizia lebbeck. Trees were significant for DBH. The power function showed highest $\overline{\mathrm{R}}^{2}(0.96)$ for branch and leaves with DBH and case of Height of tree power function showed highest $\overline{\mathrm{R}}^{2}(0.48)$.

Albizia lebbeck showed significant allometric relations for estimating aboveground biomass
(ABG) based on DBH as well as tree Height when used independently. The results revealed that power function was strong with adj $\overline{\mathrm{R}}^{2}$ (0.95) and similarly, stronger relationships were found for tree Height variable with maximum $\overline{\mathrm{R}}^{2}$ values by power function (0.47).

\section{Acacia mollissima}

Among based on DBH, the allometric relations were significant, where power function reported highest $\overline{\mathrm{R}}^{2}(0.99)$ and for tree Height variable, the significant relationships were stronger with maximum value of $\overline{\mathrm{R}}^{2}$ $(0.52)$ for sigmoid.

Allometric relations for estimating stem biomass with $\mathrm{DBH}$ as well as tree Height separately for Acacia mollissima. The power function reported highest $\overline{\mathrm{R}}^{2}(0.98)$ on the basis of DBH and for tree Height variable, the significant relationships were stronger with maximum value of $\overline{\mathrm{R}}^{2}$ for sigmoid (0.51).

Various linear and non-linear relationships used for DBH as well as tree Height for branch and leaves estimation of Acacia mollissima. Trees were significant for $\mathrm{DBH}$. The power function showed highest $\overline{\mathrm{R}}^{2}(0.96)$ for branch and leaves with DBH and however, in case of Height of tree sigmoid function showed highest $\overline{\mathrm{R}}^{2}(0.45)$.

Various linear and non-linear relationships used DBH as well as tree Height for stem volume estimation of Acacia mollissima. Trees were more significant for DBH. The power function showed highest $\overline{\mathrm{R}}^{2}(0.97)$ and in case of Height of tree sigmoid function showed highest $\overline{\mathrm{R}}^{2}(0.53)$.

\section{Toona ciliata}

Toona ciliata showed significant allometric relations for various linear and non-linear functions used for stem volume estimation 
with DBH as well as height when used independently. The results revealed that power function was strong with $\overline{\mathrm{R}}^{2}(0.88)$ on the basis of DBH and similarly stronger relationships were found for tree Height variable with maximum value of $\overline{\mathrm{R}}^{2}$ by sigmoid function (0.64).

The allometric relations for estimating stem biomass with $\mathrm{DBH}$, where power function was strong with $\overline{\mathrm{R}}^{2}(0.87)$ and similarly stronger relationships were found for tree Height variable with maximum value of $\overline{\mathrm{R}}^{2}$ by sigmoid function (0.64).

Various linear and non linear relationships used for DBH as well as tree Height for branch and leaves estimation, trees were significant for DBH. The power function showed highest $\overline{\mathrm{R}}^{2}(0.88)$ for branch and leaves with DBH and in case of Height of tree sigmoid function showed highest $\overline{\mathrm{R}}^{2}(0.64)$.

Allometric relations for estimating aboveground biomass (AGB) based on DBH. The results revealed that power function was strong with adj $\overline{\mathrm{R}}^{2}(0.87)$ and also, stronger relationships were found for tree Height variable with maximum $\overline{\mathrm{R}}^{2}$ values by sigmoid function (0.63).

\section{Dalbergia sissoo}

Various linear and non-linear equations used to find out stem volume of this tree with DBH as well as height independently were significant. The power function showed highest $\overline{\mathrm{R}}^{2}(0.99)$ value based on DBH and In case of height of tree sigmoid function is the best fitted and highest $\overline{\mathrm{R}}^{2}(0.54)$ value.

Allometric relations for estimating stem biomass of Dalbergia sissoo trees with DBH showed The power function is best with highest $\overline{\mathrm{R}}^{2}(0.98)$ value and In case of height of tree, sigmoid function is the best fitted and highest $\bar{R}^{2}(0.54)$ value. Various linear and non linear relationships for branch and leaves estimated based on DBH the power function showed highest $\overline{\mathrm{R}}^{2}(0.98)$ and However, in case of Height of tree sigmoid function showed highest $\overline{\mathrm{R}}^{2}(0.55)$.

Table.1 Calculation of Aboveground biomass (AGB), belowground biomass (BGB), Total biomass (TB), aboveground carbon (AGC) and Total carbon storage TC of selected trees

\begin{tabular}{|c|c|c|c|c|c|}
\hline TREE & \multicolumn{3}{|c|}{ Biomass (kg/ Tree) } & \multicolumn{2}{c|}{ Carbon (kg/tree) } \\
\hline $\begin{array}{c}\text { SPECIES } \\
\text { Aboveground } \\
\text { (AGB) }\end{array}$ & $\begin{array}{c}\text { Belowground } \\
\text { (BGB) }\end{array}$ & $\begin{array}{c}\text { Total } \\
\text { biomass } \\
\text { TB }\end{array}$ & $\begin{array}{c}\text { Aboveground } \\
\text { (AGC) }\end{array}$ & $\begin{array}{c}\text { Total } \\
\text { carbon } \\
\text { TC }\end{array}$ \\
\hline $\begin{array}{c}\text { Albizia } \\
\text { chinensis }\end{array}$ & 572 & 154 & $726^{ \pm} 25$ & 286 & 363 \\
\hline \begin{tabular}{c} 
Albizia lebbeck \\
\hline $\begin{array}{c}\text { Acacia } \\
\text { mollissima }\end{array}$
\end{tabular} & 800 & 220 & $1020^{ \pm} 12$ & 400 & 510 \\
\hline $\begin{array}{c}\text { Melia } \\
\text { composita }\end{array}$ & 560 & 120 & $680^{ \pm} 23$ & 280 & 340 \\
\hline Toona ciliata & 1030 & 260 & $1210^{ \pm} 29$ & 475 & 605 \\
\hline Ulmus villosa & 650 & 180 & $1310^{ \pm} 32$ & 515 & 655 \\
\hline $\begin{array}{c}\text { Dalbergia } \\
\text { sissoo }\end{array}$ & 770 & 160 & $930^{ \pm} 14$ & 325 & 415 \\
\hline
\end{tabular}


Fig.1 Scatter diagrams from carbon storage of total biomass of Albizia chinensis (A), Albizia lebbeck (B), Melia composita (C), Acacia mollissima (D), Toona ciliata (E), Ulmus villosa (F) and Dalbergia sissoo (G)

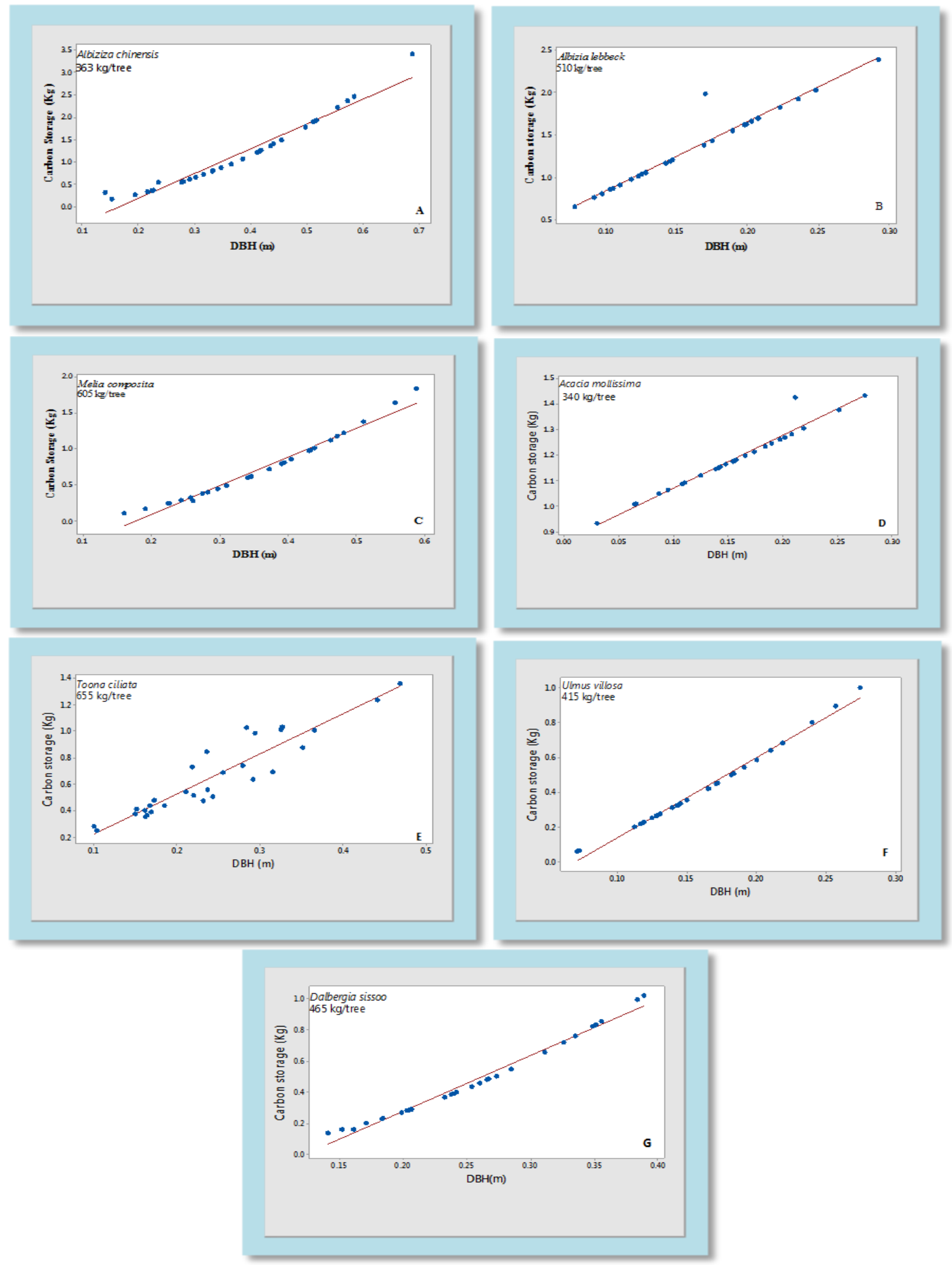


Fig.2 Scatter diagrams from carbon storage of aboveground biomass of Albizia chinensis (I), Albizia lebbeck (II), Melia composita (III), Acacia mollissima (IV), Toona ciliata (V), Ulmus villosa (VI) and Dalbergia sissoo (VII)

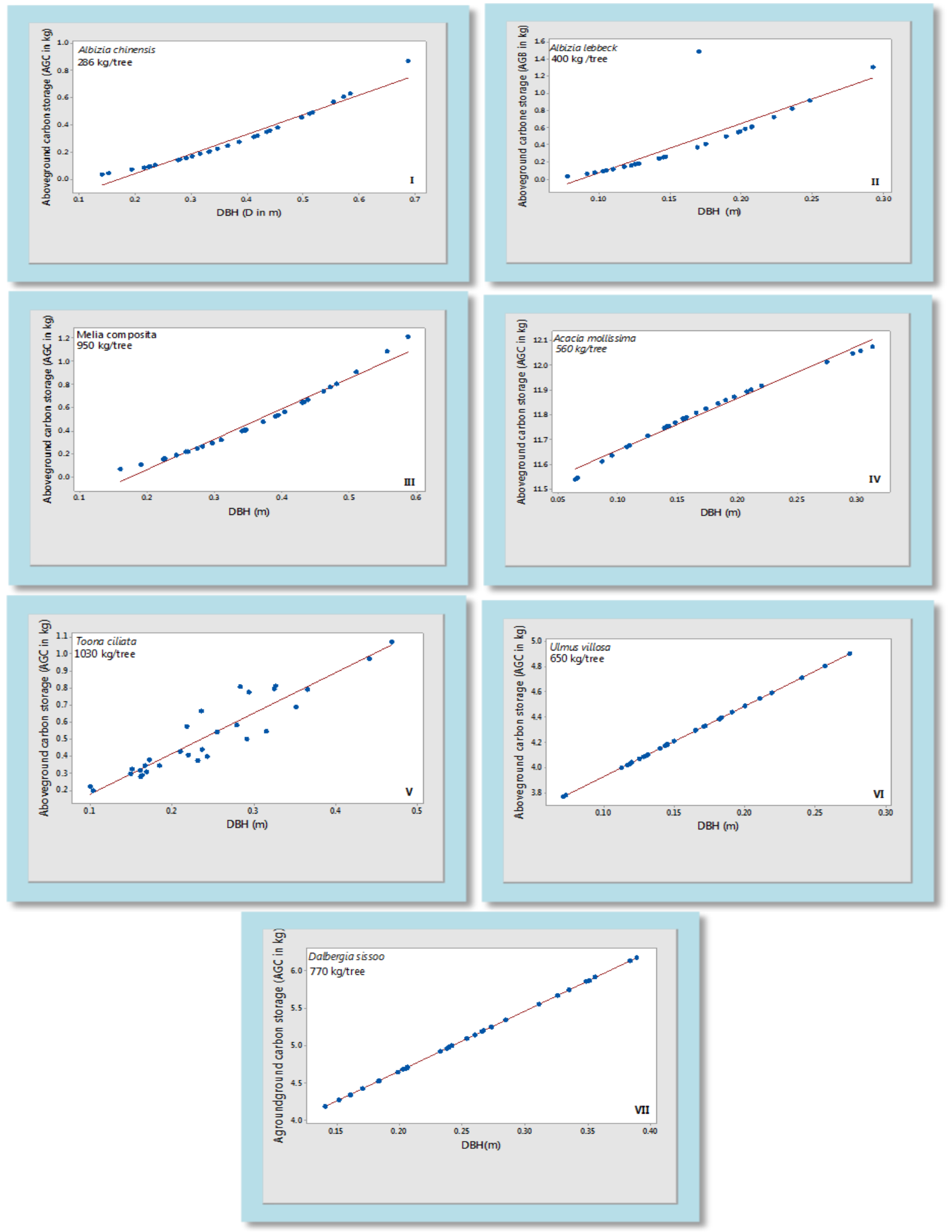


Various linear and non linear relationships used based on DBH as well as tree Height for stem volume estimation of Dalbergia sissoo. Trees were more significant for $\mathrm{DBH}$. The power function showed highest $\overline{\mathrm{R}}^{2}(0.98)$ and, in case of Height of tree sigmoid function showed highest $\overline{\mathrm{R}}^{2}(0.54)$.

The allometric relationships between stem volume and $\mathrm{DBH}$ were significant, where power function showed highest $\overline{\mathrm{R}}^{2}$ (0.98), whereas, for tree Height, the relationships were significantly strong with highest $\overline{\mathrm{R}}^{2}$ (0.59).

The allometric relations for estimating stem biomass with $\mathrm{DBH}$, where power function was strong with $\overline{\mathrm{R}}^{2}$ (0.98) and similarly stronger relationships were found for tree Height variable with maximum value of $\overline{\mathrm{R}}^{2}$ by sigmoid function (0.59).

The power function showed highest $\overline{\mathrm{R}}^{2}(0.98)$ for branch and leaves with $\mathrm{DBH}$ and however, in case of Height of tree sigmoid function showed highest $\overline{\mathrm{R}}^{2}(0.58)$.

Melia composita were more significant for $\mathrm{DBH}$. The power function showed highest $\overline{\mathrm{R}}^{2}$ (0.99) and However, in case of Height of tree sigmoid function showed highest $\overline{\mathrm{R}}^{2}(0.59)$.

\section{Ulmus villosa}

The allometric relations for estimating stem volume of Ulmus villosa tree with $\mathrm{DBH}$ and Height of tree, each taken independently, resulted in highly significant $\overline{\mathrm{R}}^{2}(0.96)$ which fitted by power function for stem volume with DBH and). In case of tree Height taken as predictor variable, sigmoid function showed highest $\overline{\mathrm{R}}^{2}$ (0.60).

The power function showed $\overline{\mathrm{R}}^{2}(0.98)$ for tree stem biomass after estimating of the allometric relations for tree stem biomass of
Ulmus villosa with $\mathrm{DBH}$ and In case of Height of tree sigmoid function showed the highest adj $\overline{\mathrm{R}}^{2}(0.59)$

Ulmus villosa were significant for $\mathrm{DBH}$. The power function showed highest $\overline{\mathrm{R}}^{2}$ (0.98) for branch and leaves biomass and in case of Height of tree sigmoid function showed highest $\overline{\mathrm{R}}^{2}(0.59)$.

Ulmus villosa showed significant allometric relations for estimating of aboveground biomass $(\mathrm{ABG})$ based on $\mathrm{DBH}$. The results revealed that power function was strong with adj $\overline{\mathrm{R}}^{2}$ (0.95) and similarly, stronger relationships were found for tree Height variable with maximum $\overline{\mathrm{R}}^{2}$ values by sigmoid function (0.62).

\section{Growth pattern and relationship among trees components}

\section{Albizia chinensis}

Growth curve pattern of morphological parameters of Albizia chinensis revealed that growth of crown area (Fig. 1) is best explained by sigmoid allometric equation $\left(\overline{\mathrm{R}}^{2}=0.41, \mathrm{SE}_{\mathrm{b} 0}=0.57\right.$ and $\left.\mathrm{SE}_{\mathrm{b} 1}=0.17\right)$.

\section{Albizia lebbeck}

Growth curve pattern of morphological parameters of Albizia lebbeck showed that growth of crown area, crown width, crown volume and height of tree are best explained by sigmoid curves with highest $\left(\overline{\mathrm{R}}^{2}=0.59\right.$, $\mathrm{SE}_{\mathrm{b} 0}=0.32$ and $\mathrm{SE}_{\mathrm{b} 1}=0.04$

\section{Acacia mollissima}

Growth curve pattern of morphological parameters of Acacia mollissima revealed that is best explained by linear allometric equations with highest $\left(\overline{\mathrm{R}}^{2}=0.19, \mathrm{SE}_{\mathrm{b} 0}=0.60\right.$ and $\mathrm{SE}_{\mathrm{b} 1}=3.69$ ). 


\section{Melia composita}

Growth curve pattern of morphological parameters of Melia composita showed that growth of crown area (Fig. 1) is best explained by sigmoid allometric equation $\left(\overline{\mathrm{R}}^{2}=0.52, \mathrm{SE}_{\mathrm{b} 0}=0.54\right.$ and $\left.\mathrm{SE}_{\mathrm{b} 1}=0.35\right)$.

\section{Toona ciliata}

Growth curve pattern of morphological parameters of Toona ciliata revealed that growth of crown area (Fig. 1) is best explained by quadratic allometric equation $\left(\overline{\mathrm{R}}^{2}=0.23, \mathrm{SE}_{\mathrm{b} 0}=1.55\right.$ and $\left.\mathrm{SE}_{\mathrm{b} 1}=0.13\right)$.

\section{Dalbergia sissoo}

Growth curve pattern of morphological parameters of Albizia lebbeck showed that is the best explained by sigmoid curves with highest $\left(\overline{\mathrm{R}}^{2}=0.44, \quad \mathrm{SE}_{\mathrm{b} 0}=0.34\right.$ and $\mathrm{SE}_{\mathrm{b} 1}=$ 0.08 ).

\section{Ulmus villosa}

Growth curve pattern of morphological parameters of Ulmus villosa revealed that is the best explained by sigmoid curves with highest $\left(\overline{\mathrm{R}}^{2}=0.33, \quad \mathrm{SE}_{\mathrm{b} 0}=0.34\right.$ and $\mathrm{SE}_{\mathrm{b} 1}=$ $0.05)$.

\section{Determination of carbon storage}

The result revealed that biomass and carbon stored in different component trees decreased in the order: Toona ciliata $>$ Melia composita $>$ Albizia lebbeck > Dalbergia sissoo > Ulmus villosa $>$ Albizia chinensis $>$ Acacia mollissima. Aboveground biomass was maximum $(1030 \mathrm{~kg} /$ tree $)$ in Toona ciliata followed by Melia composita, (950 kg/tree), Albizia lebbeck (800 kg/tree), Dalbergia sissoo $(770 \mathrm{~kg} /$ tree $)$, Ulmus villosa $(650$ $\mathrm{kg} /$ tree $)$, Albizia chinensis $(572 \mathrm{~kg} /$ tree $)$ and Acacia mollissima $(560 \quad \mathrm{~kg} /$ tree $)$.
Belowground biomass ranged from 280 $\mathrm{kg} /$ tree Toona ciliata to $120 \mathrm{~kg} /$ tree Acacia mollissima. In case of total carbon storage potential Toona ciliata has a highest rate with $(655 \mathrm{~kg} / \mathrm{tree})$.

Allometric equations are useful to measure the biomass of trees in areas. This study provides allometric equations for $\mathrm{DBH}$, height and tree biomass that can be used for forests ecosystems. It also shows that allometric equations integrating $\mathrm{DBH}$ and height of tree $(\mathrm{H})$ independently were significant variable for the estimation of tree stem volume, stem biomass, branch and leaf biomass and aboveground biomass (Fig. 2).

It is evident from the present study that there is highly significant relation between $\mathrm{DBH}$ and crown area $(\mathrm{CA})$, crown width $(\mathrm{CW})$, crown volume $(\mathrm{CV})$ and height of tree $(\mathrm{H})$ growth parameters and these growth characteristics have strongly related to dbh of tree and they increase with the increase of DBH. Among various linear and non-linear functions, the sigmoid function was the best for that component which I mentioned above. The carbon storage potential of Agroforestry tree species may be one of the important characteristics that be considered beside other factors of species selection in various part of the country. Therefore, for this sub-tropical region of Western Himalayas, the preference of the species should be in order of Toona ciliata > Melia composita > Albizia lebbeck > Dalbergia sissoo > Ulmus villosa > Albizia chinensis > Acacia mollissima.

\section{References}

Agresti A. 2007. An Introduction to Categorical Data Analysis. $2^{\text {nd }}$ ed. John Wiley and sons., New York. p 206.

Agresti A. 2013. Categorical Data Analysis. $3^{\text {rd }}$ ed. John Wiley \& Sons., New York. p 398 . 
Albrecht S and Kandji ST. 2003. Carbon Sequestration in Tropical Agroforestry System. Agriculture Ecosystem Environment 99:15-27.

Assmann E. 1970. The Principles of Forest Yield and Study. $2^{\text {nd }}$ Program, Press Ltd Oxford. p 273.

Awaya H. 1974. Mensurational studies on the relation between the density and growth in even- aged pure stand. Bulletin of Government Forest Experiment Station -Meguro 265: 1- 102.

Baes CF, Goeller HE, Olson JS and Rotty RM. 1977. Carbon dioxide and climate, The uncontrolled experiment. American Scientist 65:310-320

Balehegn M, Eniang EA and Hassen A. 2012. Estimation of browse biomass of Ficus thonningii, an indigenous multipurpose fodder tree in northern Ethiopia. African Journal of Range and Forage Science 29(1):25-30.

Beets PN, Kimberley MO, Oliver GR, Pearce SH, Graham JD and Brandon A.2012. Allometric Equations for Estimating Carbon Stocks in Natural Forest in New Zealand. Journal Forest. p 818-837.

Brown S, Sathaye J, Cannell M and Kauppi P.1996. Mitigation of carbon emission to the atmosphere by forest management. Commonwealth Forestry Review 75 (1):80-91.

Carbyn I N, Crockford K J and Sorill P S. 1988. Estimation of branchwood component of broad leaved wood lands. Journal of Forestry. 61(3): 193-204.

Carvalho PER, Neto VJAA and Dalmas J. 1987. Comparison between native and exotic forest species in Iguacu Falls area, Parana- preliminary results. Circular Técnica - Centro Nacional de Pesquisa de Florestas 15(2):9.

Chaturvedi AN and Khanna LS. 2000. Forest Mensuration and Biometry. $3^{\text {rd }}$ ed, Khanna Bandhu, Dehradun, India. $\mathrm{p}$ 364.
Chaturvedi AN and Khanna LS.1982. Forest Mensuration. International Book Distributors, Dehra Dun, Uttarakhand, India. $\mathrm{p} 407$.

Chavan BL and Rasal GB. 2010. Sequestered standing carbon stock in selective tree species grown in University campus at Aurangabad. International Journal of Engineering Science and Technology 2:3003-3007.

Chave J, Condit R, Lao S, Caspersen JP, Foster RB and Hubbell SP. 2003. Spatial and temporal variation in biomass of a tropical forest, results from a large census plot in Panama. Journal of Ecology 91:240-252.

Clark DA, Brown S, Kicklighter DW, Chambers JQ, Tomlison JR and Ni J. 2001. Measuring net primary production in forests: concepts and field methods. Ecological Applications 11:356-370.

Datta M and Singh NP. 2007. Growth characteristics of multipurpose tree species, crop productivity and soil properties in agroforestry systems under subtropical humid climate in India. Journal of Forest Research 18(4):261270.

Devi B. 2011. Biomass and carbon density under natural and plantation ecosystems in mid-hill sub-humid conditions of Himachal Pradesh. M Sc Thesis, Dr Y S Parmar University of Horticulture and Forestry, Nauni, Solan, H P, India. 55 p

Dhand VAK, Tripathi RK, Manhas JDS, Negi and Chauhan. 2003. Estimation of carbon content in some forest tree species. Indian Forester. 129(7):918922.

Djomoa, A.N., Ibrahimab, A., Saborowskic, J., and Gravenhorsta, J., (2010), Allometric equations for biomass estimations in Cameroon and pan moist tropical equations including biomass 
data from Africa, Forest Ecology and Management, 260, pp 1873-1885.

Dugarjav D and Pandey R. 2009. Modelling and validation for Volume estimation of Eucalyptus. Indian Forester 135:73-78.

Fang J, Chen A, Peng C, Zhao S and Longjun CI. 2001. Changes in forest biomass carbon storage in China between 1949 and 1998. Science 292:2320-2322.

Forslund RR and Paterson JM. 1994. Nondestructive volume estimates of 11 year old jack pine and black spruce using the power function volume model. The Forestry Chronicle 70(6): 762-767.

Garkoti SC. 2007. Estimates of biomass and primary productivity in a high-altitude maple forest of the west central Himalayas. Ecological Research 23:4149.

Grover BE, Bokalo $\mathrm{M}$ and Greenway KJ. 2014. White spruce understory protection: From planning to growth and yield. The Forestry Chronicle 90(1): 35-43.

Gujarati DN. (1998). Basic Econometrics, McGraw-Hill., New Delhi, p 705.

Gupta SC and Bhardwaj SD. 2005. Prediction of above ground biomass of black wattle in med-hills of Himachal Pradesh. Environment and Ecosystem 23(2): 319-323.

He Q, Chen Eand An R and Lee Q. (2013). Aboveground biomass estimation using allometric equation in Coniferous forest. Forest 4: 984-1002.

Hemery GE, Savill PS and Pryor SN. 2005. Applications of the crown diameter-stem diameter relationship for different species of broadleaved trees. Forest Ecology and Management 215:285-294.

Henry M, Bombelli A, Trotta C, Alessandrini A, Birigazzi L, Sola G, Vieilledent G, Santenoise P, Longuetaud F, Valentini R, Picard N and André SL. 2013. Glob AllomeTree: international platform for tree allometric equations to support volume, biomass and carbon assessment. iForest -Biogeosciences and Forestry 6: 326-330.

Hix DM and Lorimer CG. 1990. Growthcompetition relationship in young hardwood stands on two contrasting sites in Southern Wisconsin. Forest Science 36(4):1032-1049.

ICRAF Database. 2016. Wood Density, Tree Functional Attributes.

Ilyas S. 2013. Allometric Equation and Carbon Sequestration of Acacia mangium willd. Civil and Environmental Research 3:8-17.

IPCC. 2003. Guidelines for National Greenhouse Gas Inventories.

IPCC. 2006. Guidelines for National Greenhouse Gas Inventories.

Kaldy JE, Dunton KH. 2000. Above and belowground biomass, production, reproduction ecology of Thalassian testudinum in a subtropical coastal laggon. Marine Ecology Progress Series 193:271-283.

Karthik V, Ebrahim M and Geetha. 2015. Estimation of above Ground Biomass of Trees in BITS-PILANI, Dubai Campus. Energy and Biotechnology 85:93-99.

Kaushal R, Alam NM, Chaturvedi OP and Mandal D. 2014. Predictive models for biomass and carbon stock estimation in Grewia optiva on degraded land in Western Himalaya. Agroforestry System 88:895-905.

Ker MF. 1980. Tree biomass equations for ten major species in Cumberland country, Nova Scotia Canada,. Information Report. Manitimes Forest Research Centre. p 26.

Ketterings QM, Coe R, Noordwijk MV, Ambagau Y and Palm CA. 2001. Reducing uncertainty in the use of allometric biomass equations for predicting above-ground tree biomass in mixed secondary forests. Forest 
Ecology and Management 146:199209.

Keutgen, N and Chen, K. 2001 "Responses of citrus leaf photosynthesis, chlorophyll fluorescence, macronutrient and carbohydrate contents to elevated $\mathrm{CO}^{2}$." J. Plant Physiol 158, 1307-1316.

Khan MNI and Faruque O. 2010. Allometric relationships for predicting the stem volume in a Dalbergia sissoo Roxb, plantation in Bangladesh. iForest Biogeosciences and Forestry 3: 153158.

Kreanzel M, Castillo A, Moore T and Potvin C. 2003. Carbon storage of harvest age teak (Tectona grandis) plantation, Panama. Forest Ecology and Management 173(1/3):213-225.

Kumar JB, Soumyajit B, Mrinmoy M, Kumar RP and Asis M. 2009. Carbon sequestration rate and aboveground biomass carbon potential of four young species. Journal of Ecology and Natural Environment 1(2):15-24.

Laamouri A, Chtourou A and Salem HB. 2002. Above ground biomass prediction of Acacia cyanophylla Lindl. (Syn. A. saligna (Labill.) H. Wendl). Annal of Forest Science 59(3): 335-340.

Lumbres RIC, Lee YJ, Seo YO, Kim SH, Choi JK and Lee WK. (2011). Development and validation of nonlinear height-DBH models for major coniferous tree species in Korea, Forest Science and Technology 7(3):117-125.

MacDicken. 1997. Guide to monitoring carbon storage in forestry and agroforestry, Forest carbon monitoring programme. Winrock publications, New York.1-87.

Mandal RA,Yadav BKV, Yadav KK, Dutta IC and Haque SM. 2013. Development of Allometric Equation for Biomass Estimation of Eucalyptus camaldulensis Sagarnath Forest. International Journal of Biodiversity and Ecosystems 1(1):001-007.

Manhas RK, Negi JDS, Kumar R and Chauhan PS. 2006. Temporal assessment of growing stock, biomass and carbon stock of Indian forests. Climatic Change 74:191-221.

Mani S and Parthasarathy N. 2007. Aboveground biomass estimation in ten tropical dry evergreen forest sites of peninsular India. Biomass and Bioenergy 31:284-290.

Marak T and Khare N. (2017). Carbon sequestration potential of selected tree species in the campus of shuats. International Journal for Scientific Research and Development 5 (6):63-66

Matthews E, Payne R, Rohweder M and Murray S. 2000. Forest ecosystem, Carbon storage sequestration and Carbon Sequestration in Soil. Global Climate Change Digest 12:19-99.

Mbow C, Michel M, Verstraete BS, Amadou TD and Henry N. 2013. Allometric models for aboveground biomass in dry savanna trees of the Sudan and SudanGuinean ecosystem of Southern Senegal. Journal of Forest Research 19:340-347.

McPherson EG.1994. Using urban forests for energy and carbon storage. Journal of Forestry 92:36-41.

Mishra NM and Singh J. 1985. Local volume table of Acacia catechu and Lannea grandis. Indian Forestry. 111(6): 385395.

Mural KS and Bhat DM. 2005. Biomass estimation equations for tropical deciduous and evergreen forests. International Journal of Agriculture Resources, governance and ecology 4: 81-92

Murthy BNN and Devar KV. 2004. Growth and productivity studies in Acacia auirculiformis. My Forest. 40(4): 385391. 
Newaj R, Chave S, Alam B and Dhyani SK. 2016. Biomass and carbon storage in trees grown under different agroforestry system in semi arid region of central India. Indian fpresters 142 (7): 642-648.

Nizami SM. 2010. Estimation of Carbon stocks in Managed and Unmanaged Subtropical Forests of Pakistan. Ph.D. Thesis, Higher Education Commission of Pakistan, $165 \mathrm{p}$.

Ogata N, Kaminaka S, Nagatoma Y and Takeshita K.1973. Growth and production structure of Acacia mollissima De Wild. in Minamata experimental stand. Bulletin of Govt. Forest Experiment Station Meguro 252: 161-170.

Onrizal, Kusmana C, Mansor M and Hartono R. 2007. Allometric Biomass and Carbon Stock Equations of Planted Eucalyptus grandis in Toba Plateau, North Sumatra. Forestry Sciences Department, Faculty of Forestry, Malaysia. p 1-7.

Oscar BV, Mosquera GD, Morus G, Donoso MP, Marco A. Contreras. 2014. Aboveground carbon absorption in young Eucalyptus globulus plantations in Uruguay College of Forest Sciences, Chile. Science Forest Piracicaba 42(101):9-19.

Ounban W, Puangchit L and Diloksumpun S. 2016. Development of general biomass allometric equations for Tectona grandis and Eucalyptus camaldulensis Dehnh. Plantations in Thailand. Agriculture and Natural Resources 50(1):48-53

Parent G. 2000. Manual for woody biomass inventory and Woody Biomass Inventory and Strategic Planning Project, Ministry of Agriculture. Addis Ababa, Ethiopia. p 156.

Payandeh B. 1981. Choosing regression models for biomass prediction equations. Forestry Chronicle 57: 229232.

Pereira JC, Schumacher MV, Hoppe JM, Caldeira MVW and Santos EM. 1997. Biomass production in a plantation of Acacia mearnsii De Wild. Revista Árvore, Viçosa 21(4): 521-526.

Pragasan LA (2015). Total carbon stock of tree vegetation and its relationships with Altitudinal Gradient from the Shervaryan Hill located in India. Journal of Earth Science and Climate Change 6 (4) 273.

Rabha. (2014). Aboveground biomass and carbon stocks of an undisturbed regenerating sal (Shorea robusta gaertn.

f.) International Journal of Environment 3(4): 147-155.

Ranot M and Sharma DP. 2013. Carbon Storage Potential of Selected Trees in Sub-Tropical Zone of Himachal Pradesh. Journal of Tree Sciences 32 (1\&2): 28-33.

Ratul B, Santa BS and Krishna U. 2009. Distribution pattern of aboveground biomass in natural and plantation forests of humid tropics in northeast India. Tropical Ecology 50(2): 295-304.

Rawat YS, Singh SP, Usman S and Garkoti SC. 1998. Fine root biomass, productivity and root turnover in evergreen forests of Central Himalaya. Oecologia Montana 6: 4-8.

Ray PN. 1995. Estimation of tree volume models using weighted covariance analysis with dummy variables. Indian Forester 25:686-701

Ribeiro SC, Soares CPB and Jacovine LAG. 2015. Aboveground and Belowground Biomass and Carbon estimates for clonal Eucalyptus Trees in Southeast Brazil 39: 353-363.

Salunkhe O, Khare PK, Sahu TR and Singh S. (2014). Above Ground Biomass and Carbon Stocking in Tropical Deciduous Forests. Taiwania 59(4): 353-359. 
Salunkhe O, Khare PK, Sahu TR and Singh S. (2016). Estimation of tree biomass reserves in tropical deciduous forests of Central India by non-destructive approach. Tropical Ecology 57(2): 153161.

Sampaio E, Gasson P, Baracat A, Cutler D, Pareyn F and Lima KC. 2009. Tree biomass estimation in regeneration areas of tropical dry vegetation in northeast Brazil. Forest Ecology and Management 259 (6): 1135-1140.

Sanjeev K, Chauhan N, Gupta R, Yadav S and Chauhan R. 2009. Biomass and carbon allocation in different parts of agroforestry tree species. Indian Forester 135(7): 981-993.

Schneider PR, Fleig FD, Finger CAG and Kelin JEM. 2001. Growth of Black Wattle in different spacings. Cie. For 10(2): 101-112.

Schroeder P. 1992. Carbon storage potential of short rotation tropical tree plantation. Forest Ecology and Management 84(13): 355-368.

Segura O and Kanninen M. 2005. Allometric models for estimating volume and total aboveground biomass of seven dominant tree species in a tropical humid forest in Costa Rica. Center for International Forestry Research 37 (1): 2-8.

Sharma CM and Gairola S. 2007. Prospects of Carbon Management in Uttarakhand: An overview. Samaj Vigyan Shodh Patrika (Special issue-Uttarakhand- 1) pp 23-34.

Sharma CM, Gairola S, Baduni NP, Ghildiyal SK and Suyal S. 2011. Variation in carbon stocks on different slope aspects in seven major forest type of temperate region of Garhwal Himalaya. Indian Journal of Biosciences 36: 1-14.

Sharma DP and Nanda R. 2008. Volume prediction model for chirpine (Pinus roxburghii Sargant). India Journal of Forestry 31 (1): 57-60.

Sharma DP, Nanda R and Gupta D. (2009) Allometric equations to predict volume of chir pine (Pinus roxburghii Sargent) stands based on crown attributes. Journal of Tree Sciences 28 (1-2):9-15.

Sharma GK and Geyer WA. 1990. Comparative growth of agroforestry trees in mid hills of Himachal Pradesh, India. International Tree Crops Journal 6(2-3):101-111.

Singh A and Gupta NK. 2008. Growth and standing volume estimation of Cedrus deodara (Roxb.) Loud. standing under the present system of management in Himachal Himalayas - case study. Indian Forester 134(4): 458-468.

Singh M, Gupta B, Sarvade S and Awasthe RK. 2015. Biomass and carbon sequestration potential in different agroforestry systems in Giri catchment of North Western Indian Himalaya. Indian Journal of Agroforestry 17 (2): 42-48.

Sprinz PT and Burkhart HE. 1987. Relationship between tree crown, stem and stand characteristics in unthinned loblolly pine plantations. Canadian Journal of Forest Research 17:534-538.

Stavins RN and Richards KR. 2005. The cost of US. Forest based carbon sequestration. Indiana University, USA. p 1-34.

Sumida A, Miyaura T and Torii H. (2013). Relationships of tree height and diameter at breast height revisited: analyses of stem growth using 20-year data of an even-aged Chamaecyparis obtusa stand. Tree Physiology 33 (1):106-118.

Swamy SL, Bharitya TK and Mishra A. 2008. Growth, biomass, nutrient storage and crop productivity under different tree spacing's of Gmelina arborea in agri- 
silvicultural system. Indian Journal of Forestry 10(2):3-9.

Tandon VN, Pandey MC and Singh R 1989. Organic matter production and distribution of nutrients in plantations of Acacia mearnsii in Nilgiris, Tamilnadu. Indian Forest 115 (5): 286-295.

Tewari VP. 2007. Total Wood Volume Equations and their validation for Tecomella undulata plantations in hot arid region of India. Indian Forester 133: $815-820$

Tewari VP. 2016. Volume and Biomass functions for trees grown under Arid conditions in India. Indian Forester 142: 23-30.

Thakur K and Singh L. 2005. Growth and above ground biomass in short rotation Eucalyptus tereticornis $\mathrm{Sm}$. provenances. Plant Archives 5(2):441445.

Vahedi AA, Mataji A and Babay S. 2014. Allometric equation for predicting aboveground biomass of beechhornbeam stand in the Hyvcanian forest of Iran. Journal of Forest Science 6: 236-247.
Veiga RA, Carvalho CM and Brasil MAM. 2000. Tree volume equations for Acacia mangium Willd. Cerne 6(1):103-107.

Whittakar RH and Woodwell GM. 1968. Dimensional and production relations of trees and shrubs in Brookhaven forest, New York. Journal of Ecology 56:1-25.

Wilson BRSA and Daff JT. 2003. Australia's state of the forests report. Department of Agriculture, Fisheries and Forestry, Govt. of Australia. p 200.

Zanne AE, Westoby M, Falster DS, Ackerly DD, Loarie SR, Arnold SEJ and Coomes DA. 2010. Angiosperm wood structure: global patterns in vessel anatomy and their relation to wood density and potential conductivity. American Journal of Botany 97: 207215.

Zarnovican R. 1991. Volume increase of black spruce: precision of the determination. Canadian Journal of Forest Research 21: 1816-1822

Zhang Z Q. 1981. The estimation for biomass of Pinus koraiensis plantations in the east part of Heilongjiang Province. Journal of Northeast Forestry Institute $4: 85-9$

\section{How to cite this article:}

Roshanzada, S.R., K.S. Pant and Kar, S. 2018. Growth and Carbon Storage Potential of Important Agroforestry Trees of North-West Himalaya. Int.J.Curr.Microbiol.App.Sci. 7(11): 1804-1818. doi: https://doi.org/10.20546/ijcmas.2018.711.205 